\title{
Employment Contribution of Producer Services-A Case Study of Beijing
}

\author{
Hui Jia, Liyan Liu*, Baocheng Liu \\ School of Economics and Management, Beijing Institute of Petrochemical Technology, Beijing, China \\ Email: ${ }^{*}$ lucyliuliyan@bipt.edu.cn
}

How to cite this paper: Jia, H., Liu, L.Y. and Liu, B.C. (2019) Employment Contribution of Producer Services-A Case Study of Beijing. American Journal of Industrial and Business Management, 9, 1581-1595. https://doi.org/10.4236/ajibm.2019.97104

Received: July 13, 2019

Accepted: July 27, 2019

Published: July 30, 2019

Copyright $\odot 2019$ by author(s) and Scientific Research Publishing Inc. This work is licensed under the Creative Commons Attribution International License (CC BY 4.0).

http://creativecommons.org/licenses/by/4.0/

\begin{abstract}
Producer services are becoming increasingly important in the process of social and economic development. It has become one of the main indicators to measure the comprehensive competitiveness and modernization level of a region, and gradually become an important way to alleviate employment pressure and solve employment problems. Through the integrated use of employment elasticity and input-output analysis, the direct and indirect employment contribution calculation model are built in this paper to estimate the employment absorption capacity of producer services in Beijing. The present and future, the direct and indirect employment contributions of producer services are defined, and the essential characteristics of producer services sub-industries are deeply analyzed, which can provide references for Beijing to formulate future development plans and employment policies.
\end{abstract}

\section{Keywords}

Producer Services, Employment, Contribution, Estimation

\section{Introduction}

The development of the service industry has become one of the important factors to promote economic development and accelerate the urbanization process. It is also one of the important signs to measure the level of economic and social development. As an important pillar of the service industry, producer services occupy the high-end links of the industrial chain with high knowledge and high technology content, and have the characteristics of high efficiency and high radiation power. The development of producer services not only contributes to the optimization and upgrading of service industry structure, the improvement of regional independent innovation capacity and the construction of innovative ci-

${ }^{*}$ Corresponding author. 
ties [1] but also becomes the main channel to alleviate employment pressure and solve employment problems [2].

As one of the five major global cities in China, Beijing has witnessed the rapid development of producer services. In 2013, Beijing was the first Chinese city to realize the scale of producer services exceeding one trillion Yuan. The scale of producer services now accounts for more than 50\% of Beijing's economy. In recent years, a number of new industries with strong competitiveness have emerged in Beijing's information service industry, science and technology service industry and other fields, leading the continuous innovation and the development of producer services. With the scale expansion and innovative development of the industry, the employment of producer services has been increasing, which has become an important channel for employment and reemployment in Beijing.

Due to the inherent problems of the single-center urban structure, the "urban diseases" of Beijing such as population expansion, traffic congestion, housing difficulties, environmental degradation and resource shortage cannot be ignored. The task of relieving the non-capital functions of Beijing is clearly defined in The Outline of the Beijing-Tianjin-Hebei Collaborative Development Plan (2015) from the height of the national development strategy. The goal is to alleviate the prominent problems of "urban diseases" in Beijing by 2020 and basically form the regional integration pattern of Beijing, Tianjin and Hebei Province by 2030. The non-capital function settlement is a long-term process and a comprehensive project involving multiple stakeholders, which means that the industrial structure of Beijing will face huge adjustment. The industrial restructuring will undoubtedly bring about great changes in the employment situation, which is directly related to people's livelihood and social harmony. Faced with the uncertainty brought by the industrial restructuring and the change of employment situation, scientifically and reasonably measure the employment contribution of producer services, and promote the development of producer services from the perspective conducive to employment are the key points of current overall planning. It is of great strategic significance to make producer services the leading industry and the main channel of new employment for cultivating Beijing's economic and employment growth points and promoting the overall improvement of urban functions.

The main contribution of this paper is to build a direct and indirect employment contribution calculation model to estimate the employment absorption capacity of producer services in Beijing, with the aim to define the essential characteristics of producer services sub-industries and provide references for Beijing to formulate future development plans and employment policies. We estimate the employment absorption capacity of producer services through two methods, among which the employment elasticity method is mainly used to analyze the direct employment absorption capacity and has a dynamic meaning, but the defect is that it cannot fully reflect the overall employment driving effect caused by industrial correlation. The input-output method can make up for this defect, and can be used to analyze the comprehensive employment absorption capacity and 
calculate the indirect employment absorption capacity. However, the deficiency in the current application is that due to the huge amount of data survey, it is impossible to compile the table every year, and the table in a certain year is only applicable to the short-term analysis under the assumption that the relationship between industry correlation and employment absorption remains unchanged. Therefore, on the premise of the available data, the analysis of employment absorption capacity based on the estimation results of the two methods is a sub-optimal choice based on the reality.

\section{Literature Review}

There is a large literature on the service industry employment and the representative theoretical achievements include, firstly, the Petty and Clark Law expounded the relationship between the evolution of industrial structure and labor transfer, and revealed the basic law that high-end industrial structure leads to high-end employment structure [3]. Secondly, the evolution of the industrial structure of Simon Smith Kuznets showed that the industrialization process was not characterized by the shift of labor to industry, but to service sector [4]. Thirdly, Fuchs's service economy theory took statistics as the research tool and mainly adopted the method of empirical research to explain in detail the employment growth of the service sector in the historical period of transition from industrial economy to service economy and its causes and influences [5]. Fourthly, Chenery and Syrquin proposed the standard industrial structure model, and pointed out that the basic characteristic of the typical employment mode was that in the employment structure, the share of agriculture declined and the share of industry changed slowly, while the service sector absorbed a large amount of labor force transferred from the agriculture [6].

The internal rules of the service industry were further revealed by dividing the service industry into producer service industry and consumer service industry. After World War II, developed countries found that the scale of service industry was increasing, but the relative scale of public services was decreasing, and the proportion of consumer services remained basically unchanged based on the statistics of service industry output. Nevertheless, producer services, such as transportation, finance and insurance, scientific research and information services had the biggest increase [7]. Scholars increasingly realized that it was far from the goal of revealing the law of service and employment to study the whole service industry or all the sub-industries according to the division of three industries in the Petty and Clark model. Therefore, based on intermediate demand and final demand, service industry was divided into two sub-industries: producer service industry which met intermediate demand, and consumer service industry which met final demand. With human capital and knowledge capital as the main input, producer services could reduce transaction costs, promote the transfer of specialized knowledge and technology, and improve the efficiency of products and services, so they were regarded as the "lubricant" and "roll boost- 
er" of economic growth.

The employment of producer services began to attract attention with its outstanding contribution to economic growth, and scholars mainly discussed four topics:

1) The Employment Growth Rate of Producer Services, and Its Causes and Effects According to the research of Julef (1993), the employment of agriculture and manufacturing decreased by $40 \%$ and $34.8 \%$ respectively, and the employment of service industry increased by $30.4 \%$, among which the employment of producer service industry increased by $75.9 \%$ and that of other service industry increased by $22.5 \%$ from 1971 to 1989 in the UK [8]. Beyers (1999) found that from 1977 to 1996, the employment growth of producer services in the United States and Canada was twice and 3.7 times that of the overall employment growth respectively, contributing to one quarter and one third of the new employment, making it the sector with the largest labor absorption [9]. In terms of the causes of producer services employment growth, Beyers (1999) [9] and John (1987) [10] reached a consistent conclusion, that is, the rapid growth of producer services employment is not a byproduct of manufacturing scale reduction and outsourcing. The real reason was that the producer services with knowledge and human capital as the main input, on the one hand, could greatly reduce transaction costs, on the other hand make the spread of professional knowledge and technology transfer more convenient, which greatly improved the efficiency of the service, had a positive impact on the domestic economy, and the role of promoting employment growth had gone far beyond the other departments. Driver et al. (1987) studied the impact of various employment fluctuations in the British service industry on the British GDP, and they found that the fluctuations of public service industry employment did not have a cyclical impact on the gross national product, but the fluctuations of producer service industry employment had a relatively obvious impact on the gross national product [11].

2) Regional Agglomeration of Producer Services Employment Harrington and Campbell (1997) illuminated the pattern of producer services' suburbanization in the Washington, D.C., metropolitan area between 1970 and 1992. Their results showed producer services employment growing at a faster rate at locations farther from the central city [12]. Christopher et al. (2016) revisited the topic utilizing data from 2004 to 2010, and multivariate linear regression was used to estimate per capita growth of producer services employment using six independent variables. The results revealed producer services employment grew significantly more quickly in the urban D.C. core than the outer suburbs, contrary to Harrington and Campbell's research. Additionally, they found per capita producer services employment was self-limiting over the study period: Locations with more producer services employment in 2004 experienced significantly less producer services growth over the period [13]. Roland (2001) studied the employment structure of producer services in economically undeveloped areas of 
Canada, and found that the relative labor intensity of producer services in these areas was lower than that in large central cities [14]. Tompson (2004) studied the employment of producer services in Kentucky, USA, and illuminated that they were mainly concentrated in medium and large cities [15]. Zhuang Delin et al. (2018) found that the agglomeration of producer services not only significantly improved the total employment level in the region, but also promoted the employment of manufacturing industry and producer services industry in the region [16].

3) The Mechanism of Producer Services Affecting Employment Jia Hui (2013) [17] found that the expansion of traditional producer service sector and the emergence of new producer service sector firstly stimulated the rapid development of the service sector through the primary multiplier effect formed by investment, then the industry forward correlation effect and backward correlation effect enable producer services to benefit more industrial sectors. Furthermore, the newly derived demands would further promote the development of logistics, trade, finance, real estate, transportation, catering, entertainment, information and business services. Industries related to producer services would also stimulate and drive the development of many non-related industries, generating a secondary multiplier effect. The cycle of these processes constituted an open mechanism for sustained economic growth and employment growth stimulated by producer services. Chen Bin (2016) [18] explained that producer services had a high degree of industrial integration, and promoted employment growth mainly through the industry-leading effect, the synchronous effect and the correlation effect. He illuminated that producer services and the forward and backward related industries had a relationship of mutual consumption, and this relationship could effectively promote the rapid development of these industries, which would eventually affect more industries. This would not only promote the employment growth of producer services and related industries, but also promote the employment growth of other affected industries, and ultimately promote the employment growth of the whole society.

4) Empirical Study on the Employment Contribution of Producer Services Kong Lingfeng (2011) estimated the employment absorption capacity of producer services in Shanghai by means of employment elasticity and input-output method, which showed that producer services contributed significantly to the employment growth, but there were great differences in the characteristics of the employment contribution in sub-industries [19]. Che Fang and Liu Hao (2019) measured the employment effect of producer services in Chongqing by using employment elasticity, input-output indicators and structural deviation degree, and empirically analyzed relevant influencing factors. The results revealed that the direct and indirect employment effects of producer services in Chongqing were strong, and there was a large space for employment growth [20].

On the whole, Chinese and foreign scholars have demonstrated the employment problem of producer services from multiple perspectives and conducted 
systematic research, which provides a good reference for us to carry out research in this field. However, the existing literature is relatively weak in the detailed analysis of the time dimension of the employment contribution of producer services and its sub-industries, as well as the research on differentiated development countermeasures. Therefore, this paper classifies and quantifies the employment contribution of producer services and its sub-industries, including present and future employment contribution, as well as composite, direct and indirect employment contribution. In terms of research methods, most existing researches adopt employment elasticity analysis, input-output analysis and structural deviation degree analysis, indicating that these methods have been widely recognized. Based on these methods, this paper constructs a direct and indirect employment contribution calculation model by using employment elasticity and input-output analysis method. Taking Beijing as an example, this paper estimates the employment contribution of producer services, illuminates the current and future direct and indirect employment contribution of producer services sub-industries, and deeply analyzes the essential characteristics of producer services sub-industries, so as to provide references for Beijing to formulate future development plans and employment policies.

\section{The General Approach}

When studying the employment problem of the industry, we should not only consider the number of jobs directly created by the industry itself, but also consider the jobs indirectly created by relevant industries driven by the development of the industry. This paper divides employment into direct employment and indirect employment, and uses two methods to measure the employment absorption capacity of producer services in Beijing.

1) Direct Employment Absorption Capacity When measuring direct employment absorption capacity, the employment elasticity $(E)$ method is adopted, that is, the percentage change of employment quantity $(L)$ corresponding to every one percentage point change in economic growth $(Y)$, and its calculation formula is:

$$
E=(\Delta L / L) /(\Delta Y / Y)
$$

In Equation (1): The greater the employment elasticity $(E)$ is, the greater the role of output growth in stimulating employment, and the stronger the ability to absorb direct employment, otherwise, the reverse is true. However, since the employment elasticity formula (1) can only calculate the elasticity within a certain period (generally one year), the overall elasticity in consecutive years cannot be calculated, and the errors caused by abnormal data fluctuations cannot be eliminated. In order to estimate the employment elasticity more accurately and make it suitable for prediction, this paper constructs a nonlinear model between economic growth and employment, and its formula is:

$$
L=A Y^{\alpha} \mathrm{e}^{\mu}
$$

In formula (2): $L$ is the number of jobs in the industry, $A$ is the constant coef- 
ficient, $Y$ is the GDP, $\alpha$ is the employment elasticity, and $\mu$ is the random error term. If we take the logarithm of both sides of Equation (2), we get:

$$
\ln L=\ln A+\alpha \ln Y+\mu
$$

The coefficient $\alpha$ in formula (3) is the desired employment elasticity, that is, the percentage of employment growth driven by every 1 percentage point increase in output value.

2) Indirect Employment Absorption Capacity Due to the correlation between industries, there is also an indirect consumption relationship in addition to direct consumption in the production process of any product. Therefore, the production volume of a certain sector is generally larger than the quantity of final product, and the total labor input required is also greater than the labor input directly reflected in the industry, and the excess part is the industry's indirect employment absorption capacity. Based on the industrial relevance theory and the input-output analysis method established by Leontief [21], this paper builds an employment contribution calculation model and calculates the indirect employment absorption capacity on the basis of comprehensive employment absorption capacity. The employment contribution calculation model can be used to calculate the employment contribution generated by every 10,000 Yuan invested by industrial sectors of the national economy. Through the analysis and comparison of employment coefficient, the employment demand ability of different industrial sectors is studied. The so-called employment coefficient analysis is to study the use of labor by the target industry and its contribution to social employment from the perspective of the remuneration of workers in the target industry. The detailed calculation process and application are shown below:

On the basis of the input-output table, the direct employment coefficient of sector $i$ is set as $D L_{p}$ the indirect employment coefficient as $I L_{p}$ and the composite employment coefficient as $G L_{\dot{r}}$. The direct employment coefficient $D L_{i}$ can be used to represent the employment opportunities directly created by the target industry. The calculation method is the proportion of the total remuneration received by the workers in the industry to the total input. The composite employment coefficient $G L_{i}$ of sector $i$ can be expressed as:

$$
\begin{gathered}
G L_{i}=D L_{i}+I L_{i} \\
G L_{i}=D L_{i}+\sum_{j=1}^{n}\left(G L_{j}-h_{i j}\right)(i, j=1,2 \cdots, n)
\end{gathered}
$$

In formula (5): $h_{i j}$ represents the ratio of the output of department $i$ taken as intermediate products by department $j$ to the total output of department $i$, and it is the $f^{\text {th }}$ element in the vector of intermediate product distribution coefficient in department $i$.

$$
\begin{gathered}
h_{i j}=X_{i j} / X_{i}(i, j=1,2, \cdots, n) \\
H=\left(\begin{array}{ccc}
h_{11} & \cdots & h_{1 n} \\
\vdots & \ddots & \vdots \\
h_{n 1} & \cdots & h_{n n}
\end{array}\right)
\end{gathered}
$$


In formula (5): $G L_{j}-h_{i j}$ represents the indirect employment contribution of increased output in sector $i$ to output in sector $j$ : every unit increase in the output of sector $i$ will lead to the increase in the consumption of intermediate products of sector $j$, and finally lead to the employment increase in sector $j$. The matrix is denoted by:

$$
G L=D L+H \times G L
$$

In matrix (7):

$$
\begin{aligned}
& D L=\left(D L_{1}, D L_{2}, \cdots, D L_{n}\right)^{\mathrm{T}} \\
& G L=\left(G L_{1}, G L_{2}, \cdots, G L_{n}\right)^{\mathrm{T}}
\end{aligned}
$$

Substitute Equation (8) and Equation (9) into matrix Equation (7), and we can get $(I-H) \times G L=D L$, and that is:

$$
G L=(I-H)^{-1} \times D L
$$

The econometric model can be used to calculate the direct employment coefficient, composite employment coefficient and indirect employment coefficient of various industries in the national economy, so as to measure the comprehensive employment contribution and indirect employment contribution brought by each industrial sector per ten thousand Yuan of input. The different employment coefficients show different employment demand capacities of different industrial sectors.

\section{Data Description}

1) Producer Services It mainly refers to the market-oriented intermediate input services. Although the concept has been widely used, there are still some differences in the understanding of its basic connotation. Statistical Classification Standard for Producer Services in Beijing (Beijing series No. 2009 [11]) widely reference the theory of service sector classification at home and abroad, considering the concrete conditions of China and Beijing, in accordance with the main functions of the service activities, and divide the services into three categories, namely, producer services, consumer services and public services. In the Industrial Classification of National Economy (GB/T 4754-2002), six industrial categories are included in producer services, including Transportation, Storage and Post, Information Transmission, Computer Services and Software, Wholesale Trade and Retail Trade, Finance, Tenancy and Commercial Services, Scientific Studies, Technical Services and Geological Prospecting. According to the characteristics of business activities, producer services are divided into five categories: circulation services, information services, financial services, business services and technological services.

2) Direct Employment Absorption Capacity When calculating the employment elasticity of producer services and its sub-industries, the industry classification data in Beijing Statistical Yearbook (2000-2018) are used directly, including transportation, storage and post, information transmission, computer 
services and software, wholesale trade and retail trade, finance, tenancy and commercial services, scientific studies, technical services and geological prospecting. The data of year-end employed persons in urban units (grouped by sector) from 2000 to 2017 are used, and employed persons include fully employed staff and workers at their posts, retired and VCSR engaged and kept on, personnel of foreign, Hongkong, Macao and Taiwan, and other employed persons. Regard 2000 as the base year, the nominal GDP of the current year is adjusted by GDP deflator to eliminate the factor of rising prices in GDP. E-views 8.0 software is used to carry out ordinary least square (OLS) estimation on service industry, non-producer service industry, producer service industry and its internal sub-industries by using formula (3).

3) Indirect Employment Absorption Capacity Input and output data of 139 sectors are mainly derived from 2012 Beijing Input and Output Table. The input-output survey of Beijing is relatively systematic, and the input-output table provided by Beijing reflects the technical and economic relationship between the input and output, the production and distribution of products in various industries within a certain period. The input-output coefficient is a technical parameter, less affected by other social factors, and it is of considerable accuracy. However, as a quantitative research method, input-output analysis has its limitations and errors. Therefore, the analysis in this paper is not to obtain authoritative statistical data, and the results only provide decision-making reference for relevant departments. In order to make a better comparison and analysis, the data of 139 sectors in the input-output table are classified, and the data summarized including transportation, storage and post, information transmission, computer services and software, wholesale trade and retail trade, finance, tenancy and commercial services, scientific studies, technical services and geological prospecting. Using the input, output and remuneration data of these sub-industries, the indirect employment contribution model (formula 5) is adopted to calculate the employment coefficient of producer services in Beijing, including the direct and composite employment coefficients, indirect employment coefficients and indirect employment ratios of various sub-industries within producer services.

\section{Empirical Results}

1) Direct Employment Absorption Capacity of Producer Services Firstly, it takes the service industry as an example to calculate the direct employment absorption capacity (employment elasticity). Based on the service industry employed persons $\left(L_{s}\right)$ and GDP value $\left(Y_{s}\right)$ from 2000 to 2017, OLS estimates (Table 1) are developed through E-views 8.0. The estimation result is shown in Equation (11):

$$
L N L_{s}=4.719+0.624 * L N Y_{s}
$$

As shown in Table 1, the Durbin-Watson stat is 0.201 , which is significantly less than the critical value 2 at the significance level of 0.05 , indicating that there is a serious first-order positive correlation of residual term with time. Hence, Cochrane-Orcutt iteration method was adopted and $A R(1)$ was introduced to 
Table 1. OLS Estimation (1).

\begin{tabular}{|c|c|c|c|c|}
\hline \multicolumn{3}{|c|}{ Sample: $2000-2017$} & & \\
\hline \multicolumn{5}{|c|}{ Included observations: 18} \\
\hline Variable & Coefficient & Std. Error & $\mathrm{t}$-Statistic & Prob. \\
\hline C & 4.719701 & 0.121251 & 21.89371 & 0.0000 \\
\hline$L N L_{s}$ & 0.624133 & 0.041201 & 44.49913 & 0.0000 \\
\hline R-squared & 0.969721 & \multicolumn{2}{|c|}{ Mean dependent var } & 9.121815 \\
\hline Adjusted R-squared & 0.971939 & \multicolumn{2}{|c|}{ S.D. dependent var } & 0.443729 \\
\hline F-statistic & 1087.601 & \multicolumn{2}{|c|}{ Durbin-Watson stat } & 0.201709 \\
\hline Prob (F-statistic) & 0.000000 & & & \\
\hline
\end{tabular}

modify it (Table 2), and the modified estimation result is shown in Equation (12):

$$
L N L_{s}=7.131+0.405 * L N Y_{s}+[A R(1)=0.917]
$$

As shown in Table 2, the regression results have passed $\mathrm{t}$ test and $\mathrm{F}$ test, and Durbin-Watson stat is 2.302 indicating the autocorrelation is eliminated. The adjusted R-squared is 0.991 after modification, indicating that the model fits well. The results of the estimation (Equation (12)) show that the employment elasticity of the service industry is 0.405 , which means every $1 \%$ increase in the GDP of the service industry, the number of people employed rose by $40.5 \%$. Using the same method, regression analysis is carried out for non-producer service industry, producer service industry and its internal sub-industries respectively (Table 3).

As shown in Table 3, the overall employment elasticity of the service industry in Beijing is 0.405, non-producer services are 0.382, while the employment elasticity of the producer service industry is 0.556 , which is significantly higher than that of non-producer services and the service industry as a whole, implying prominent direct employment contribution. Furthermore, the employment elasticity of all the sub-industries of producer services is higher than that of the whole service industry, which indicates that Beijing producer services have a strong ability to absorb direct employment and has shown a trend similar to that of developed countries in recent years. Nevertheless, there are obvious differences in the direct employment absorption capacity of the sub-industries. The employment elasticity of finance (0.851), information transmission, computer services and software (0.743), transportation, storage and post (0.691), tenancy and commercial services (0.593) are all higher than that of producer services (0.556). However, the employment elasticity of scientific studies, technical services and geological prospecting (0.461), wholesale trade and retail trade (0.457) are both lower than that of producer services $(0.556)$. If only from the perspective of direct employment absorption capacity, it means that the sub-industries with higher elasticity coefficient make greater contribution to solving the 
Table 2. OLS Estimation (2).

\begin{tabular}{ccccc}
\hline \multicolumn{5}{c}{$\begin{array}{c}\text { Sample (adjusted): 2000-2017 } \\
\text { Included observations: } 17 \text { after adjustments }\end{array}$} \\
\cline { 1 - 3 } Convergence achieved after 4 iterations \\
\cline { 1 - 3 } Variable & Coefficient & Std. Error & t-Statistic & Prob. \\
\hline$C$ & 7.131729 & 0.095113 & 7.121471 & 0.0000 \\
$L N L_{s}$ & 0.405112 & 0.089301 & 2.037913 & 0.0291 \\
$A R(1)$ & 0.917255 & 0.015510 & 49.02328 & 0.0000 \\
R-squared & 0.997170 & Mean dependent var & 9.490312 \\
Adjusted R-squared & 0.991213 & S.D. dependent var & 0.510931 \\
F-statistic & 1810.514 & Durbin-Watson stat & 2.302997 \\
Prob (F-statistic) & 0.000000 & & \\
Inverted AR Roots & 0.95 & & \\
\hline
\end{tabular}

Table 3. Estimation of employment elasticity of Beijing service industry and internal sub-industries.

\begin{tabular}{|c|c|c|c|c|c|c|}
\hline Industry/Sub-industry & $\begin{array}{l}\text { Coefficient } \\
\text { (Elasticity) }\end{array}$ & $\begin{array}{l}\text { Std. } \\
\text { Error }\end{array}$ & R-squared & $\begin{array}{c}\text { Adjusted } \\
\text { R-squared }\end{array}$ & F-statistic & $\begin{array}{c}\text { Durbin-Watson } \\
\text { stat }\end{array}$ \\
\hline Service Industry & 0.405 & 0.089 & 0.997 & 0.991 & 1810.514 & 2.302 \\
\hline $\begin{array}{l}\text { Producer Service } \\
\text { Industry }\end{array}$ & 0.556 & 0.097 & 0.988 & 0.973 & 724.301 & 1.759 \\
\hline $\begin{array}{l}\text { Non-producer } \\
\text { Service Industry }\end{array}$ & 0.382 & 0.112 & 0.985 & 0.970 & 521.701 & 1.473 \\
\hline $\begin{array}{l}\text { Transportation, } \\
\text { Storage and Post }\end{array}$ & 0.691 & 0.073 & 0.848 & 0.810 & 22.321 & 2.635 \\
\hline $\begin{array}{l}\text { Information } \\
\text { Transmission, } \\
\text { Computer Services } \\
\text { and Software }\end{array}$ & 0.743 & 0.107 & 0.958 & 0.930 & 34.084 & 1.803 \\
\hline $\begin{array}{l}\text { Wholesale Trade } \\
\text { and Retail Trade }\end{array}$ & 0.457 & 0.052 & 0.851 & 0.839 & 8.562 & 1.427 \\
\hline Finance & 0.851 & 0.081 & 0.949 & 0.915 & 27.881 & 1.383 \\
\hline $\begin{array}{l}\text { Tenancy and } \\
\text { Commercial Services }\end{array}$ & 0.593 & 0.072 & 0.984 & 0.981 & 111.489 & 2.403 \\
\hline $\begin{array}{l}\text { Scientific Studies, } \\
\text { Technical Services and } \\
\text { Geological Prospecting }\end{array}$ & 0.461 & 0.047 & 0.973 & 0.955 & 53.844 & 1.811 \\
\hline
\end{tabular}

Note: The regression results have passed $\mathrm{t}$ test and $\mathrm{F}$ test. The D-W stat shows that autocorrelation is eliminated at the significance level of 0.05 , and the adjusted R-squared shows that the model fits well.

employment problem in Beijing.

2) Indirect Employment Absorption Capacity of Producer Services As shown in Table 4, the labor-intensive tenancy and commercial services have the highest composite employment coefficient (0.391) and indirect employment ratio (49.1), indicating the strongest comprehensive and indirect employment 
Table 4. Estimation of indirect employment absorption capacity of producer services in Beijing.

\begin{tabular}{|c|c|c|c|c|}
\hline Producer Services Sub-industries & $\begin{array}{c}\text { Direct } \\
\text { Employment } \\
\text { Coefficient }\end{array}$ & $\begin{array}{l}\text { Composite } \\
\text { Employment } \\
\text { Coefficient }\end{array}$ & $\begin{array}{c}\text { Indirect } \\
\text { Employment } \\
\text { Coefficient }\end{array}$ & $\begin{array}{c}\text { Proportion } \\
\text { of Indirect } \\
\text { Employment }\end{array}$ \\
\hline Transportation, Storage and Post & 0.142 & 0.278 & 0.136 & 48.7 \\
\hline $\begin{array}{l}\text { Information Transmission, Computer } \\
\text { Services and Software }\end{array}$ & 0.181 & 0.295 & 0.114 & 38.7 \\
\hline Wholesale Trade and Retail Trade & 0.221 & 0.332 & 0.111 & 33.5 \\
\hline Finance & 0.175 & 0.281 & 0.106 & 37.8 \\
\hline Tenancy and Commercial Services & 0.202 & 0.391 & 0.189 & 49.1 \\
\hline $\begin{array}{l}\text { Scientific Studies, Technical Services } \\
\text { and Geological Prospecting }\end{array}$ & 0.171 & 0.322 & 0.151 & 46.9 \\
\hline
\end{tabular}

Table 5. Employment contribution of producer services sub-industries.

\begin{tabular}{lccc}
\hline \multicolumn{1}{c}{ Producer Services Sub-industries } & $\begin{array}{c}\text { Present } \\
\text { Employment } \\
\text { Contribution }\end{array}$ & $\begin{array}{c}\text { Future Direct } \\
\text { Employment } \\
\text { Contribution }\end{array}$ & $\begin{array}{c}\text { Future Indirect } \\
\text { Employment } \\
\text { Contribution }\end{array}$ \\
\hline Transportation, Storage and Post & $\star$ & $\star \star$ & $\star \star \star$ \\
Finance & $\star$ & $\star \star \star$ & $\star$ \\
Information Transmission, Computer & $\star \star$ & $\star \star \star$ & $\star \star$ \\
Services and Software & $\star \star$ & $\star$ & $\star \star$ \\
Scientific Studies, Technical Service and & $\star \star \star$ & $\star$ & $\star$ \\
Geological Prospecting & $\star \star \star$ & $\star \star$ & $\star \star \star$ \\
Wholesale Trade and Retail Trade & & & \\
Tenancy and Commercial Services & & & $\star$ \\
\hline
\end{tabular}

absorption capacity. With the quality upgrading of new e-commerce industry in Beijing, the innovation of platform construction technology, and the continuous breakthrough of trading mode, the influence of this industry will continue to increase, and its comprehensive driving effect on employment is unlimited. The direct employment coefficient (0.142) and the composite employment coefficient (0.278) of transportation, storage and post are both low, but the indirect employment coefficient (0.136) and the proportion of indirect employment (48.7) are high, indicating that their indirect employment contribution is large and their potential for future employment absorption is strong. With the continuous improvement of Beijing's infrastructure, the basic establishment of modern logistics system, and further improvement of market concentration, this industry will develop great potential for employment growth in the future. The proportion of indirect employment in scientific studies, technical services and geological prospecting (46.9) show that its indirect employment contribution ranks the third place. If only from the perspective of indirect employment coefficient and the proportion of indirect employment, it means that within producer services, finance, wholesale trade and retail trade make relatively small indi- 
rect contribution to solving the employment problem in Beijing.

3) Present and Future Prospects of the Employment Contribution of Producer Services Promoting the development of producer services is not only the inevitable requirement of accelerating the industrial restructuring and upgrading in Beijing, but also the best choice to deal with the challenge of employment. From the perspective of employment policy making, if we assume that the relationship between industry correlation and employment absorption will not change significantly in a certain period of time in the future, we can give a rough picture of the present and future employment contribution of various sub-industries of producer services. "Present employment contribution" is mainly divided by the composite employment coefficient, "future direct employment contribution" is mainly divided by the employment elasticity, and "future indirect employment contribution" is mainly divided by the proportion of indirect employment. The sub-industries were entitled three stars if the coefficient is numerically ranked $1^{\text {st }}$ and $2^{\text {nd }}$ place, two stars if ranked $3^{\text {rd }}$ and $4^{\text {th }}$ place, and one star if ranked $5^{\text {th }}$ and $6^{\text {th }}$ place, as shown in Table 5 . It enables us to have a more comprehensive understanding of the relationship between the direct and indirect contribution, long-term and short-term contribution of various sub-industries to employment growth when thinking about employment issues, and provides a directional reference for implementing differentiated employment promotion policies.

The main result in Table 5 reveals that, firstly, from the perspective of the current employment contribution, the highest contribution is from tenancy and commercial services, wholesale trade and retail trade. The next is scientific studies, technical services and geological prospecting, information transmission, computer services and software. The lowest contribution is from finance, as well as transportation, storage and post. Secondly, from the perspective of future direct employment contribution, the highest contribution value is the finance sector, information transmission, computer services and software. Thirdly, from the perspective of future indirect employment contribution, the highest contribution is from tenancy and commercial services, as well as transportation, storage and post.

\section{Conclusions}

Through the integrated use of employment elasticity and input-output analysis, the employment contribution calculation models are built in this paper to estimate the employment absorption capacity of producer services in Beijing. By comprehensively weighing the direct and indirect employment contribution of various sub-industries of producer services at present and in the future, and combining the orientation of Beijing's future development target and the essential characteristics of producer services, corresponding policy suggestions on industrial and employment promotion are put forward.

Firstly, information transmission, computer service and software, and the 
finance sector are two sub-industries with the current employment contribution being small, but the future direct employment contribution being large. The government should give priority and key support to the design of specific employment promotion policies, such as talent training, talent introduction, flow of talented personnel and talent motivation, so as to attract more high-quality talents from home and abroad to devote themselves to the development of this two sub-industries, and further improve the comprehensive employment absorption capacity on the basis of improving the direct employment absorption capacity.

Secondly, transportation, storage and postal services followed by scientific studies, technical services and geological prospecting are two sub-industries with relatively high indirect employment contribution in the future. The government should break the monopoly to promote the introduction of advanced technology and management mode, promote the correlation between these two sub-industries and other industries, enhance their production service attributes, and further improve their ability to absorb indirect employment as the policy focus.

Thirdly, the largest present employment contribution is attributed to two labor-intensive sub-industries, namely, tenancy and commercial services, wholesale trade and retail trade. On the one hand, the government should promote large-scale and chain operation of large enterprise groups by improving the competitive service pattern of multiple types of enterprises, so as to give full play to their ability to absorb employment directly. On the other hand, workers should be provided with opportunities in skills training and necessary supports in information services to ensure their employment stability and flexibility.

\section{Conflicts of Interest}

The author declares no conflicts of interest regarding the publication of this paper.

\section{Supporting Projects}

1) Employment Effects of Producer Services in Beijing, Beijing Municipal Education Commission Project (SM201610017001). 2) Employment Support for Land-lost Farmers of Daxing District in Beijing--from the Perspective of Three-dimensional Capital, Beijing Social Science Foundation Research Base Project (16JDSRC008). 3) The Coupling Mechanism between FDI and Employment Structure in Beijing, Beijing Municipal Education Commission Project (SM201510017001). 4) The Optimization of Beijing's Industrial Structure Based on SFDI, Beijing Social Science Foundation Project (13JGC072). 5) Employment Effects of Producer Services in Beijing, Beijing URT Project (2018J00210).

\section{References}

[1] Cao, C. and Chen, X. (2019) Development Model, Structural Adjustment and Urban Economic Growth of Producer Services-An Empirical Study Based on Dynamic Spatial Durbin Model. Management Review, 31, 17-28.

[2] Wood, P.A. (2007) The Anatomy of Job Loss and Job Creation-Some Speculations 
on the Role of the Producer Service Sector. Regional Studies, 36, 37-46. https://doi.org/10.1080/09595238600185041

[3] Zhang, S. (2002) Employment Changes in the Process of Globalization. China Finance and Economics Press.

[4] Kuznets, S. (1955) Economic Growth and Income Inequality. American Economic Review, 45, 1 .

[5] Fuchs, V.R. (1987) Service Economics. The Commercial Press, Shanghai.

[6] Syrquin, M. and Chenery, H.B. (1989) Three Decades of Industrialization. The World Bank Review, 3, 152-153. https://doi.org/10.1093/wber/3.2.145

[7] Gruber, H.C. and Walker, M.A. (1993) The Growth of the Service Industry: Reasons and Effects. Shanghai Sanlian Bookstore, Shanghai, 220.

[8] Juleff, D.L. (1993) The Structure of Advanced Producer Service Employment in Great Britain, 1971-1989. Social Science Working Paper, No. 4, 1-14.

[9] Beyers, W.B. (1999) There's Gold in Them There Producer Services. Policy Options, 11, 36-39.

[10] TscheRer, J. (1987) Producer Services Industries: Why Are They Growing So Rapidly. Monthly Labor Review, 12, 31-39.

[11] Driver, C. and Naisbitt, B. (1987) Cyclical Variations in Service Industries' Employment in the UK. Applied Economics, 19, 541-554. https://doi.org/10.1080/00036848700000022

[12] Harrington, J.W. and Campbell, H.S. (1997) The Suburbanization of Producer Service Employment. Growth and Change, 28, 335-346. https://doi.org/10.1111/j.1468-2257.1997.tb00983.x

[13] Christopher, S.C., Vese, R.D., Boyd, M.A., Reddy, A.D., Mulhollen, A.P., Zand, D.E., et al. (2016) Servicing Our Economy: Producer Service Location and Government Procurement 2004-2010 in the Washington DC Metropolitan Area. Growth and Change, 47, 631-647. https://doi.org/10.1111/grow.12159

[14] Roland, B. (2001) Employment Structure in Rural and Small Town-Canada: The Producer Services Sector. Agriculture \& Rural Working Paper, 31-47.

[15] Tompson, E.C. (2004) Producer Services. Kentucky Annual Economic Report, 1-56.

[16] Zhuang, D., Wu, J., Yang, Y. and Jin, S. (2017) Can Collaborative Agglomeration of Producer Services and Manufacturing Promote Employment Growth. Journal of Guizhou University of Finance and Economics, 190, 59-68.

[17] Jia, H. (2013) Study on Employment and Influencing Factors of Producer Services in China. Doctoral Dissertation, Capital University of Economics and Business.

[18] Chen, B. (2016) The Transmission Mechanism of Producer Services Affecting Employment-Based on the Case Study of Guigang City. Journal of Guangxi University of Finance and Economics, 2, 92-102.

[19] Kong, L. (2011) Empirical Study on Employment Absorption Capacity of Producer Services in Shanghai. Population and Economics, 2, 33-38.

[20] Che, F. and Liu, H. (2019) Analysis of Urban Producer Services Employment Effect and Its Influencing Factors. Statistics and Decision, 10, 145-148.

[21] Binsha, J. and Zou, W. (1993) Development of Input-Output Analysis Methods. Statistical Research, 10, 32-36. 